Migration Studies - Review of Polish Diaspora nr 4 (174)/2019, http://www.ejournals.eu/Studia-Migracyjne/ DOI: 10.4467/25444972SMPP.19.039.11353

\title{
Między Starym a Nowym Światem - podobieństwa, różnice, szanse i ograniczenia
}

\author{
JOANNA DMUCHAŁA ${ }^{1}$ \\ Uniwersytet Jagielloński
}

Przybywszy do Stanów Zjednoczonych na przełomie XIX i XX wieku polskie emigrantki znalazły się w obcym często nieprzyjaznym środowisku. Pomimo różnic kulturowych, nieznające języka i obyczajów Polki w USA kreowały siebie oraz własną/nową przestrzeń wykraczając poza granice świata domowego i angażując się w szeroko pojęte życie społeczne. Od końca XIX wieku kobiety polskiego pochodzenia tworzyły system oświatowy, który pozwał im na pracę w ramach wspólnoty etnicznej, zakładały sierocińce, działały w stowarzyszeniach dobroczynnych, organizowały strajki i bojkoty, udowadniając tym samym swoją polityczną siłę. Korzystając z istniejących w społeczeństwie amerykańskim swobód zrzeszania się oraz wyniesionych z kraju pochodzenia tradycji solidarności i samopomocy sąsiedzkiej, polskie emigrantki zaczęły zakładać lokalne towarzystwa wzajemnej pomocy, które pod koniec lat 80. XIX w. zjednoczyły się w jednej, centralnej organizacji, tworząc w 1898 roku Związek Polek w Ameryce, zapewniający kobietom ubezpieczenie, dbałość o zachowanie świadomości narodowej oraz emancypację.

Słowa kluczowe: emigracja do USA, migrantki, aktywizacja

\section{Between the Old and the New World: Similarities, Differences, Opportunities and Limitations}

Having arrived in the United States at the turn of the 19th and 20th centuries, Polish emigrants found themselves in a foreign and often unfriendly environment. Despite cultural differences, Polish women who did not know the language and American traditions were able to create themselves and their own/new space by transcending the borders of the home world and through involvement in social life. From the end of the 19th century, women of Polish origin had created an educational system that allowed them to work within their ethnic community, establish orphanages, work in charitable associations and organize strikes and boycotts, thus proving their political strength. Taking advantage of the freedom of association existing in American society and the tradition of

\footnotetext{
1 Kontakt: joanna.dmuchala@gmail.com
} 
solidarity and self-help in the neighborhood, Polish immigrant women began to establish local societies of mutual assistance, which in 1898 united in one central organization - the Polish Women's Union in America - providing women with insurance, care for the preservation of national identity and emancipation.

Key words: emigration to the USA, female migrants, emancipation

\section{Wprowadzenie}

Polscy emigranci, którzy w II połowie XIX wieku przybyli do Stanów Zjednoczonych, przywieźli ze sobą, ułatwiające im adaptację do nowej rzeczywistości, różnorakie formy życia społecznego. I tak stopniowo poprzez parafię, towarzystwa przykościelne, prasę, aż po organizacje polonijne rozwijała się działalność Polaków w Ameryce. Jaka była rola kobiet polskiego pochodzenia w kształtowaniu tych instytucji? Jakie społeczeństwo i środowisko kulturowe opuszczały polskie imigrantki? I w konsekwencji, w jaki sposób ich kultura, europejska przeszłość wpłynęły na przystosowanie do życia w Ameryce?

Celem niniejszego tekstu będzie znalezienie odpowiedzi na powyższe pytania. Skupiam się w nim na zaakcentowaniu wątków emancypacyjnych zarówno w Polsce pod zaborami, jak i w Stanach Zjednoczonych. Opierając się na analizie dokumentów, przedstawiam okoliczności, w jakich doszło do powstania największej polonijnej organizacji kobiecej - Związku Polek w Ameryce, a przede wszystkim wpływu, jaki miało założenie własnej organizacji na usamodzielnienie i równouprawnienie polskich emigrantek. Pomijam jednocześnie działalność innych organizacji polonijnych (Zjednoczenie Polskie Rzymsko-Katolickie - ZPRzK oraz Zjednoczenie Narodowo-Polskie ZNP), jak i z racji ograniczeń objętościowych dokładną analizę środowiska polonijnego na przełomie XIX i XX wieku. Na polu badań nad polską grupą etniczną w Stanach Zjednoczonych zauważalny jest brak szczegółowych analiz poświęconych roli kobiet w życiu organizacyjnym Polonii. Za pozycje najbliższe omawianej kwestii można uznać serię trzech monografii napisaną przez działaczki Związku Polek w Ameryce. Pierwszy tom autorstwa Jadwigi Karłowiczowej (1938), drugi Marii Loryś (1980) i trzeci Helen Zieliński (1981) oraz wydanego stosunkowo niedawno opracowania, mającego charakter tradycyjnej monografii podporządkowanej chronologicznemu przeglądowi dziejów organizacji, napisanego z okazji 100-letniej rocznicy powstania Związku Polek w Ameryce, autorstwa Angeli i Donalda Pienkos (2003).

\section{Aktywność kobiet pod zaborami}

Polki w XIX wieku emigrowały z ojczyzny, która nie tylko pozbawiona była niezależnej państwowości, podzielona na trzy zabory, ale także z przestrzeni publicznej, w której kobietom odmawiano zarówno praw politycznych - przede wszystkim 


\section{SM̂PP}

wyborczych - ale także możliwości do w pełni swobodnego zrzeszania się (Żarnowska 2013: 197). Podstawowe, nasuwające się w tym miejscu pytania brzmią: jak w takich warunkach kształtowała się i czy w ogóle miała szansę zaistnieć kobieca aktywność w polskim wydaniu? I czy w sytuacji nieistniejącego państwa polskiego można mówić o występowaniu dychotomii, między sferą publiczną, zarezerwowaną dla działalności mężczyzn, a sferą prywatną, przypisywaną kobiecie?²

Kobiety w XIX wieku na obszarach wszystkich trzech zaborów podlegały tradycyjnemu, patriarchalnemu, głęboko zakorzenionemu w świadomości społecznej modelowi rodziny, w którym role społeczne były ściśle uzależnione od płci. Z jednej strony kobiety dbały o dzieci, gotowały i szyły - pełniły więc istotną funkcję w organizacji życia codziennego rodziny. Silnie angażowały się również w tradycyjne formy zbiorowego świętowania, zarówno z okazji świąt rodzinnych, jak i religijnych, umacniając tym samym poczucie wspólnoty (Żarnowska 2013: 164). Z drugiej strony, w warunkach braku własnego państwa, kiedy szczególną wagę przywiązywano do zachowania dziedzictwa polskiej kultury narodowej, kobiety, zgodnie z tradycyjnymi wzorcami wychowawczymi, odgrywały bardzo istotną rolę, dbając o podtrzymanie takich wartości, jak przywiązanie do ziemi, języka czy religii (Stegmann 1997: 364). W tym kontekście sfera prywatna, będąca domeną kobiet, nabrała zupełnie innego, wręcz mitycznego znaczenia - z rodziną jako twierdzą polskości, której zadaniem było przeciwstawienie się uciskowi zaborcy oraz kobietą w roli "symbolicznej strażniczki Narodu" (Kraft 2005: 151-152). Było to efektem odmiennie ukształtowanej linii podziału między sferą prywatną a sferą publiczną w kraju bez własnej państwowości, w porównaniu z innymi państwami Europy czy Stanami Zjednoczonymi. W rezultacie w przypadku Polski pod zaborami możemy tak naprawdę wyróżnić rozgraniczenie sfery publicznej społeczeństwa obywatelskiego, naznaczonej walką o niepodległość, od sfery publicznej państwa nadzorowanej przez zaborców (Kraft 2005: 150).

Wobec braku własnych instytucji demokratycznych i narodowych "jedną z nielicznych spójnych struktur umożliwiających organizowanie się społeczeństwa stał się Kościół katolicki", a życie religijne z kolei, szczególnie na szczeblu parafii, pełniło funkcję zastępczej formy działalności publicznej (Żarnowska 2013: 199). Należy jednak zaznaczyć, iż Kościół katolicki ograniczał aktywność kobiet głównie do roli matki i żony, a udział w życiu religijnym miał je dodatkowo w tych zadaniach utwierdzać. Paradoksalnie jednak, zaangażowanie w działalność parafialną stało się dla kobiet szansą na wzrost ich autorytetu, nie tylko w rodzinie, ale i w szerszej społeczności lokalnej, w wykraczających poza funkcje matki i żony, rolach. Inicjowanie z kolei przez

2 Sfera prywatna uważana była za domenę kobiet i wiązano ją z instytucją rodziny, macierzyństwa, wychowaniem dzieci i rolą żony. Sfera publiczna obejmowała natomiast aktywność zawodową i polityczną, miała być obszarem działania mężczyzn. „W ten sposób sytuowanie ról kobiecych i męskich w treściowo odmiennych kontekstach działań, prywatnym i publicznym, wyznaczało «właściwe» sposoby bycia kobietą i mężczyzną" (Bokszańska 2004: 143). 
parafię różnych wydarzeń, pozwalało kobietom na, czasami jedyny, kontakt z życiem publicznym (Żarnowska 2013: 199).

Ten religijno-parafialny wariant aktywności publicznej polskich kobiet znalazł też swoją alternatywną wersję w ich dążeniach emancypacyjnych. W polskich warunkach bowiem, w odróżnieniu przykładowo od angielskich sufrażystek, nie tyle walka o prawa polityczne, co narodowe, stanowiła pierwszy impuls do samoorganizowania się kobiet. Impuls nie tylko istotny, ale często wręcz jedyny (Żarnowska, Szwarc 2013: 211). Aktywność w ruchu narodowym stała się dla Polek pod zaborami (szczególnie tych pochodzących z warstw tzw. oświeconych) rodzajem surogatu ruchu emancypacyjnego zgodnego z zachodnioeuropejskim wzorem. Pozbawione bowiem możliwości jawnego i legalnego działania we własnych kobiecych organizacjach i w świetle tradycyjnych wyobrażeń o roli kobiety, były często zmuszane do "kamuflowania” swoich rzeczywistych dążeń emancypacyjnych (Żarnowska 2013: 197). Zastępcze formy organizowania się zwolenniczek równouprawnienia widoczne były w prowadzonej przez nie działalności oświatowej. Tajne nauczanie w języku macierzystym w szkółkach na wsi czy w mieście, stało się dla wielu kobiet szansą na zdobycie umiejętności organizacyjnych, jak i nabycie doświadczeń kierowniczych w działalności publicznej. Aktywność edukacyjna w kraju pozbawionym własnego państwa niewątpliwie dała również okazję do współuczestniczenia w tworzeniu nietypowych form organizowania się ruchu kobiecego, pomimo konkurencyjnych inicjatyw Kościoła katolickiego (Żarnowska, Szwarc 2013: 216). Pozwoliła jednocześnie na ukształtowanie się szczególnego typu aktywistek identyfikujących się raczej jako działaczki społeczne niż feministki i walczące w pierwszej kolejności z dyskryminacją narodową, nie zaś z dyskryminacją płci (Żarnowska, Szwarc 2013: 217).

Okoliczności, w jakich krystalizowała się i rozwijała aktywność Polek, były efektem wzajemnego przenikania się zarówno wyjątkowej sytuacji Polski pod zaborami, gdzie prawa do samorealizacji kobiet zastąpione zostały obowiązkiem wobec wspólnoty narodowej, jak i katolickiego modelu "matki Polki"3.

\section{Nowy Świat - nowe możliwości}

W momencie przybycia do Ameryki imigrantki z terenów polskich w swoim „bagażu kulturowym" przywiozły potrzeby i przyzwyczajenia wyniesione głównie z dziewiętnastowiecznej wiejskiej społeczności lokalnej. W nowych warunkach wyznaczały one nie tylko poziom aspiracji, ale i potrzeby społeczne (Praszałowicz 1986: 35; Brożek 1988: 14). Mając poczucie obcości i zagubienia emigranci próbowali odtworzyć,

${ }^{3}$ Mit "matki Polki” nie tylko idealizuje kobietę jako nosicielkę tożsamości narodowej. Jednocześnie pokazuje opresyjny charakter kultury, pozbawiający kobietę podmiotowości, traktując ją jak „przedmiot narzędzie kultury i polityki". W rezultacie kobieta staje się ważna tylko wymiarze symbolicznym, nie realnym (Warat 2008: 69-70). 


\section{SM̂PP}

znane im ze Starego Kraju struktury. „Porządek społeczny, jaki się tu zaczął wytwarzać, wyrastał z tych treści społecznych i zwyczajów, obyczajów i pojęć moralnych i organizacyjnych, które ze sobą i w sobie przynieśli" - pisał Józef Chałasiński (1935: 636) W pierwszym rzędzie należały do nich instytucje religijne, głównie parafie ${ }^{4}$, które - poza religijną - pełniły również funkcje wspólnotowe, dlatego cechował je znaczny stopień totalności (Babiński 2009: 130, Znaniecka-Łopata 1977: 92).

Początkowo pobożne emigrantki zrzeszały się więc głównie w przyparafialnych kółkach różańcowych ${ }^{5}$. Zadaniem kobiet w tego typu organizacjach, poza wspólnym odmawianiem modlitw, była praca na rzecz kościoła, w zamian za którą otrzymywały niekiedy wsparcie w czasie choroby, pośmiertne odszkodowanie lub pokrycie kosztów pogrzebu (Karłowiczowa 1938: 14).

W nowej amerykańskiej rzeczywistości życie organizacyjne polskich imigrantów wyznaczała również edukacja prowadzona w parafiach. I Poprawka do Konstytucji Stanów Zjednoczonych z 1791 roku , zapewniająca swobodę religijną, sprzyjała również powstawaniu etnicznych szkół parafialnych z daleko posuniętą autonomią ${ }^{7}$. Ich prowadzeniem zajmowały się głównie siostry zakonne (Praszałowicz 1986: 27). W konsekwencji zakony zaczęły odgrywać jedną z kluczowych ról w kształtowaniu życia polonijnego.

W celu zapewnienia niezbędnej dla powstającego szkolnictwa parafialnego kadry nauczycielskiej, sprowadzano z Europy żeńskie zakony religijne oraz zakładano nowe na miejscu. „I dziś tak jak dawniej, na straży tego wszystkiego co dobre, co nasze, bo polskie, stoi kobieta - Siostra Nauczycielka w polskiej szkole, bo ona Strażniczka" pisano w prasie polonijnej (Głos Polek 1927, nr 19: 1) W 1874 roku na zaproszenie ks. Józefa Dąbrowskiego, byłego żołnierza powstania styczniowego, przyjechały do Stanów Zjednoczonych felicjanki, by m.in. nauczać polskie dzieci ${ }^{8}$ Przybyłe wówczas

${ }^{4}$ Zdaniem Leonarda F. Chrobota parafia polska pomogła emigrantom polskim przejść od tradycyjnej społeczności wioskowej (Gemeinschaft) do społeczności miejskiej (Gesellschaft) (1982: 81-95). Tworzenie etnicznych parafii nie było zjawiskiem powszechnym, np. w przypadku emigracji czeskiej, której uczestnicy założyli stosunkowo niewiele parafii i organizacji przyparafialnych (Babiński 2009: 285-286)

5 Joseph J. Parot, analizując dane z polskiej dzielnicy w południowym Chicago końca XIX wieku, zauważył, iż działalność kobiet w tego typu parafialnych stowarzyszeniach mogła mieć zasadniczy wpływ na trwałość małżeństw i rodzin polskich imigrantów (1982: 155-182).

${ }^{6}$ Wolność religijna w Stanach Zjednoczonych została wyznaczona przez funkcjonowanie dwóch klauzul konstytucyjnych; klauzuli ustanowienia (establishment clause) oraz klauzuli swobody praktyk religijnych (free excercise clause). „Klauzula ustanowienia oznacza przede wszystkim rozdział państwa od Kościoła, brak funkcjonowania oficjalnej religii państwowej, zakaz tworzenia przez państwo związków wyznaniowych, zakaz promowania jakiegokolwiek wyznania względem pozostałych oraz obowiązek tworzenia ustawodawstwa, które nie będzie traktowało żadnej religii w odmienny sposób niż pozostałe". Klauzula swobodnego praktykowania religii z kolei „oznacza przede wszystkim zakaz ingerencji państwa w formę i sposób wyrażania praktyk religijnych" (Laidler 2007: 110-111).

7 Imigranci polscy, podobnie jak słowaccy, wielkim nakładem środków tworzyli własne szkoły parafialne. Emigranci włoscy z kolei nie tworzyli szkół lub robili to bardzo rzadko, korzystali więc podobnie jak emigranci żydowscy ze szkół publicznych (Walaszek 1993: 51-52).

${ }^{8}$ Więcej informacji na temat założycielki felicjanek można znaleźć w artykule (Doman 1953: 65-94). 
cztery siostry z Moniką Sybilską stały się pionierkami edukacji w polskich szkołach parafialnych przez religijne zakony polonijne. W 1882 roku w Detroit zakonnice utworzyły własne seminarium, zwane Akademią Felicjanek (Felicjan Academy) (Encyklopedia katolicka 1989: 102; Taras 1989: 182). Prowadziły także szkoły college, jako instytucje wyższego stopnia nauczania, wśród nich była m.in. Madonna College w Livonii ${ }^{9}$. Felicjanki w USA zajmowały się nie tylko nauczaniem dzieci polskich emigrantów przy parafiach, ale również wydawały podręczniki oraz opracowały własny program nauczania (Praszałowicz 1988: 226; Encyklopedia katolicka 1989: 103).

Drugim, przybyłym do Stanów Zjednoczonych polskim zakonem było założone przez Polkę bł. Franciszkę Siedlecką ${ }^{10}$ w 1873 roku w Rzymie Zgromadzenie Najświętszej Rodziny z Nazaretu. Pierwsze 12 sióstr nazaretanek dotarło do Chicago w 1885 roku. Ich celem stało się nauczanie w szkołach polonijnych. W 1887 roku założyły w tym mieście akademię pod wezwaniem Najświętszej Rodziny, która przez długi okres była jedyną polonijną szkołą średnią dla dziewcząt. Jedną z najbardziej zasłużonych w pracy pedagogicznej sióstr nazaretanek była wieloletnia przełożona tej placówki edukacyjnej Matka Maria Stanisława (Kumor 1995: 336; Kruszka 1937: 119; Wachtl 1944: 143) ${ }^{11}$. Biorąc pod uwagę aktywność oświatową zakon nazaretanek był w tej dziedzinie drugim po felicjankach. Nazaretanki stworzyły w USA także placówki opiekuńcze, w których zajmowały się sierotami oraz pielęgnowały chorych. Od 1894 roku prowadziły również Szpital Najświętszej Marii Panny z Nazaret w Chicago. Był to jedyny polski szpital urządzony zgodnie z najnowszymi metodami i zaopatrzony w potrzebną aparaturę medyczną (Praszałowicz 1988: 232; Andrzejewski, Dziembowska 1977: 221).

Niewątpliwie zasięg działalności polskich żeńskich zakonów religijnych w USA był imponujący ${ }^{12}$. Chociaż główną funkcją zgromadzeń religijnych w Stanach Zjednoczonych (w przeciwieństwie do Europy) była edukacja ${ }^{13}$, to siostry nie tylko zakładały,

${ }^{9}$ Dzieje Madonna College w Livonii były typowym przykładem przemian, jakim uległ polonijny college prowadzony przez zakon żeński: ewolucji od żeńskiej szkoły zakonnej szczebla średniego do koedukacyjnej placówki oświaty wyższej, którą stał się oficjalnie w 1972 roku. Historii Madonna College w Livonii poświęcona była praca doktorska obroniona w Wayne State University (Kujawa 1979). Zob. Praszałowicz 1988: 232.

${ }^{10} \mathrm{Na}$ temat Franciszki Siedleckiej, zob. Liguori [Pakowska] 1946: 30-35.

11 Matka Maria Stanisława (Józefina Sierpińska) urodziła się w Krakowie 9 marca 1863 roku. Skończyła krakowską szkołę św. Scholastyki, w wieku osiemnastu lat wstąpiła do Zgromadzenia Sióstr Nazaretanek. Po rocznym pobycie w zakonie została przeniesiona do Rzymu, a następnie w celu podjęcia pracy misyjnej do Ameryki i była jedną z pierwszych dwunastu nazaretanek, które przybyły do pracy wśród Polonii Amerykańskiej, w której udzielała się przez 27 lat. Uczyła kolejno w następujących polskich szkołach: w Scranton, w Chicago, Filadelfii, Pittsburghu, w Cleveland i ponownie w Chicago. We wszystkich tych szkołach zajmowała w sumie przez ponad 20 lat stanowisko przełożonej. Następnie została powołana na asystentkę prowincjonalnej i przełożonej Akademii Najświętszej Rodziny w Chicago, zmarła pełniąc tę funkcję 2 lutego 1912 roku. (Wachtl 1944: 143; Leś 1981: 170).

${ }_{12} \mathrm{Z}$ uwagi na ograniczone miejsce $\mathrm{w}$ niniejszym artykule pozwoliłam sobie wspomnieć jedynie o dwóch najaktywniejszych pod kątem polonijnej działalności oświatowej zakonach.

${ }^{13}$ Na początku XX wieku zaczęły w środowisku polonijnym pojawiać się szkoły języka polskiego, które prowadziły osoby świeckie. W 1908 roku było w Chicago sześć takich szkół, a zasłużonymi propagatorkami 


\section{SM̂PP}

nadzorowały czy prowadziły szkoły, ale także opiekowały się sierocińcami czy domami dla osób w podeszłym wieku. Z zasięgu tych działań wynikała niezwykle istotna i rozbudowana pozycja sióstr zakonnych na przełomie XIX i XX wieku (Galush 1996: 86)14. W rezultacie aktywność kobiet świeckich w Kościele katolickim w porównaniu z innymi wyznaniami, należała do najbardziej ograniczonych ${ }^{15}$. Poza wspominanymi już kółkami różańcowymi, pozostawiono im jedynie wąski margines możliwych działań, takich jak zbieranie datków na drobne usługi parafialne czy „utrzymanie w czystości świątyń Pańskich" (Nowaczewska 2010: 227; Karłowiczowa 1938: 2).

Z drugiej strony należy jednak pamiętać, iż pochodzące głównie z obszarów wiejskich polskie imigrantki po przybyciu do Stanów Zjednoczonych osiedlały się przede wszystkim w miejskich ośrodkach przemysłowych ${ }^{16}$. Dzięki zmianie środowiska społecznego z homogenicznej, kontrolującej swoich członków wspólnoty wiejskiej, na otwartą i dynamiczną społeczność miejską, kobiety polskiego pochodzenia zyskały okazję do skorzystania z nowych, nieznanych dotąd możliwości (Knothe 2005: 182). Jedną z niezwykle istotnych zmian było podjęcie pracy poza domem. Było to zjawisko powszechne - badania wskazują, że wszystkie niezamężne kobiety były aktywne zawodowo (Radziallowski 1996: 75). Polskie emigrantki pracowały w rozmaitych miejscach: w pralniach, sklepach, restauracjach i garkuchniach, ale także w fabrykach (Anker 1988: 30-31).

Nieco inaczej sprawa aktywności zawodowej wyglądała w przypadku kobiet zamężnych. Należy bowiem pamiętać o utrwalanym i funkcjonującym w XIX wieku w społeczeństwie amerykańskim modelu rodziny patriarchalnej, który stanowił jedną z istotnych przyczyn ograniczenia niezależnej działalności kobiet. Ciągle żywy był również mit mężczyzny jako jedynego żywiciela rodziny oraz kobiety pracującej nie z konieczności, ale dla spełnienia własnych zachcianek. W rzeczywistości w rodzinach biednych, szczególnie wywodzących się z mniejszości narodowych, praca kobiet i dzieci17 stawała się koniecznością, ponieważ zarobki mężczyzny często nie

języka polskiego na terenie tego miasta były wówczas m.in. Janina Dunin i Jadwiga Krasowska-Stopowa. Rocznie do tych szkół uczęszczało około tysiąca uczniów. W 1932 roku w Chicago działało już szesnaście szkół języka polskiego z trzema tysiącami uczniów (Pastusiak 1978: 9).

${ }_{14}$ Dzisiejsze studiowanie katolickich, żeńskich społeczności zakonnych zostało znacznie poszerzone tematycznie przez historyczki feministyczne, takie jak np. Misner (1988).

${ }^{15}$ Zmiany w podejściu polskiego duchowieństwa do roli kobiet zaczęły być widoczne już na początku XX. Dowodem czego miała być m.in. struktura hierarchiczna w Polskim Stowarzyszeniu Dobroczynności z Chicago, założonym przez pierwszego polonijnego biskupa - Paula Rhode. W tym stowarzyszeniu na poziomie parafii zarówno kobiety, jaki i duszpasterze oraz laicy byli traktowani jako równi sobie urzędnicy (Galush 1990: 11; Karłowiczowa 1938: 21).

${ }^{16} \mathrm{O}$ reakcji różnych grup etnicznych na życie w amerykańskim mieście i pracę w chicagowskich rzeźniach na przełomie XIX i XX wieku pisał m.in. James Barrett (1987).

17 Dzieci, które urodziły się w Stanach Zjednoczonych, znajdowały się w szczególnie trudnej sytuacji tzW. "marginalności” - zawierającej się pomiędzy kulturą wyniesioną z Polski a kulturą amerykańską. Zmuszone do podjęcia decyzji, który z światów jest im bliższy, stawały się jednocześnie przewodnikami rodziców tłumaczącymi im USA (Rokicki 1992: 47; Walaszek 1993: 59, Głos Polek 1937 nr 2: 6). 
wystarczały na utrzymanie rodziny (Nowaczewska 2010: 231-232). „[...] z powstaniem fabryk w otoczeniu niewiasty zaszła wielka zmiana [...]. Z producentki domowej nie wynagradzanej pieniędzmi za swą pracę stała się najemną robotnicą w fabryce, przynoszącą do domu pod koniec każdego tygodnia koperty z pieniędzmi. Była to olbrzymia zmiana, która uwydatniła się o wiele silniej w jej obecnym stanowisku społecznym, aniżeli w charakterze pracy samej" (Głos Polek 1926, nr 7: 1; Głos Polek 1928, nr 35: 1). Z kolei praca dzieci była w pełni sankcjonowana w polskich społecznościach imigranckich, w których ściśle kontrolowano ich zarobki powiększające budżet rodzinny. Adam Walaszek uważa, że takie zachowania były efektem wpływu rodzimej kultury chłopskiej, w której traktowano ciężką pracę całej rodziny, w tym kobiet i dzieci, jako rzecz naturalną (Walaszek 1988) ${ }^{18}$.

W wyniku konieczności przystosowania się do nowych warunków życia i pracy, emigrantki podejmowały również nieznane im dotychczas role, także te o charakterze publicznym ${ }^{19}$. Angażowały się między innymi w rozmaite kwestie dotyczące interesu publicznego, takie jak ochrona zdrowia, poprawa systemu bezpieczeństwa czy dbanie o czystą wodę (Walaszek 2007: 285) ${ }^{20}$. Zwiastunem zmian było również coraz większe angażowanie się Polek w prace na rzecz pomocy społecznej. Pod koniec XIX wieku w „etniczną dobroczynność”, która była do tej pory domeną głównie mężczyzn i duchowieństwa, coraz wyraźniej wkraczały kobiety. Przykładem takiego zaangażowania był projekt uruchomienia polskiego szpitala, z którym szczególnie związana była Anna Klarkowska. Wraz z mężem Bolesławem Klarkowskim i innymi lekarzami wspierała kampanię na rzecz powstania etnicznego szpitala, który otwarto w 1894 r. Kilka lat później w 1905 roku w Chicago Towarzystwo Dobroczynności pod opieką św. Elżbiety, z pomocą sióstr franciszkanek, otworzyło klinikę oraz zajęło się rozprowadzaniem funduszy dla biednych Polaków (Karłowiczowa 1938: 21). Pod koniec XIX wieku polskie emigrantki zajmowały się dobroczynnością, tworzyły sierocińce i dbały o kulturę życia codziennego. Pracowały dla społeczności lokalnej, z którą były związane, aby zapewnić nie tylko jej trwanie, ale i sprawne funkcjonowanie. Coraz śmielej wkraczały więc w sferę aktywności zarezerwowaną dotąd dla mężczyzn (Walaszek 2007: 286).

18 Kwestia pracy zarobkowej kobiet i dzieci różniła się w zależności od konkretnej grupy etnicznej. Przykładowo w rodzinach Afro-Amerykanów kobiety pracowały między innymi przyjmując sublokatorów, ale dzieci nie musiały dokładać się do budżetu rodzinnego. Włosi z kolei chętniej wysłali do pracy dzieci niż kobiety, często poza domem pracowały kobiety pochodzenia żydowskiego (Bodnar, Weber 1982; Weinberg 1988).

19 Helena Znaniecka-Łopata na przykładzie społeczeństwa amerykańskiego pisała o tym, iż „[...] ideologia dwóch sfer, którą rozwinęli Amerykanie, nie tylko oddziela życie prywatne od publicznego, ale także zawiera w sobie model stratyfikacji, w którym sfera publiczna znajduje się ponad sferą prywatną i w ten sposób tworzy stratyfikację według płci" (1997: 536). Z kolei Agnieszka Graff pisze, iż w oczach postępowych Amerykanów, przeciwników niewolnictwa, „wykluczenia kobiet z sfery publicznej nie traktowano jako problemu, bo przecież kobiety z założenia do tej sfery nie należały" (2004: 56).

20 Niektórzy badacze w takiej wolontaryjnej działalności kobiet doszukiwali się źródeł feminizmu. 


\section{SM̂PP}

Osiągnięta za Oceanem nowa - aktywna - pozycja kobiet polskiego pochodzenia ujawniła się szczególnie $w$ dotychczas niespotykanym wymiarze podczas wielkiego kryzysu ekonomicznego ${ }^{21}$. Jakkolwiek już wcześniej obserwowano dowody zaangażowania się kobiet polskiego pochodzenia w obronę interesów klasowych. W 1885 roku w Cleveland podczas głośnego strajku kobiety na równi z mężczyznami nie tylko dyskutowały o taktyce walki, ale również pikietowały przed bramą fabryki Rolling Mills, Co., a 14 lipca, gdy tłum przed zakładem zaatakował policję, to właśnie kobiety obrzuciły kamieniami uzbrojonych funkcjonariuszy rozpoczynając atak ${ }^{22}$. Jak relacjonowały gazety: „Niewieście przyjaciółki strajkujących przybywały na scenę wydarzeń z chustami pełnymi cegieł i innych pocisków" (cyt za: Walaszek 1994: 100). Polki, wspólnie z mężczyznami i dziećmi, atakowały również łamistrajków podczas strajku tramwajarzy w Cleveland w czerwcu, lipcu i sierpniu 1899 roku. 22 września 1910 roku siedemnaście polskich imigrantek rozpoczęło strajk w firmie Hart, Schaffner i Marx. "Wyszłyśmy wszystkie, chciałyśmy by widziano w nas ludzi”, mówiły strajkujące (Walaszek 1988: 175). W założonym po miesiącu komitecie strajkowym działała m.in. Franciszka Jankiewicz (Walaszek 1988: 175).

\section{Samopomoc i kobieca solidarność}

Kontakty sąsiedzkie dla Polek w kraju pochodzenia stanowiły okazję nie tylko do artykułowania swoich poglądów, odpoczynku od obowiązków domowych, ale i opierały się - szczególnie w społecznościach o chłopskim rodowodzie - na tradycji solidarności i samopomocy w ramach pokrewieństwa i sąsiedztwa (Wawrykiewicz 1985: 48)23. "Często zażyłość była tak wielka, że matki karmiły własną piersią niemowlęta pracujących sąsiadek" (Taras 1989: 54). W nowych społeczno-przestrzennych warunkach miast amerykańskich, imigrantki pozbawione zostały pomocy "tych, których [...] we-

${ }^{21}$ W czasie kryzysu ekonomicznego lat 30. XX wieku dotychczasowe role w rodzinie polonijnej niejednokrotnie ulegały zamianie. Często bowiem to kobieta nie tylko pracowała poza domem, ale również go utrzymywała. Budziło to krytykę Kościoła katolickiego. A. Walaszek przywołuje wypowiedź księdza Wiktora ze szkoły św. Trójcy w Chicago, który mówił: „Autokratyczna dominacja i znaczenie głowy rodziny są poważnie zachwiane. Musicie pamiętać, że rodzina polska opiera się na władzy, nie na miłości... Prestiż mężczyzny, dawnej głowy rodziny, maleje, gdy zmuszony on jest prosić kobiety i dzieci o pieniądze na drobne wydatki" (1997: 284).

22 Zachowania emigrantów, czy byli oni wojowniczy czy pasywni, zależały w dużej mierze od ich przedemigracyjnych doświadczeń - uważa John Bodnar (1985). Adam Walaszek z kolei wskazuje na podobieństwa działań imigrantów robotników z obyczajami polskiej wsi. Przykładowo konflikty przemysłowe przypominały gwałtowne bunty chłopskie (1988).

${ }^{23}$ Rodzina ze szczególnie istotną rolą kobiety w organizacji życia domowego, w dziewiętnastowiecznej społeczności wsi polskiej, traktowana była jak instytucja społeczna, pozostająca częścią szerszego układu krewniaczo-sąsiedzkiego. Rodzinna solidarność natomiast przejawiała się, zarówno w udzielaniu pomocy najbliższym, jak i sprawowaniu kontroli nad pozostałymi członkami grupy (Thomas, Znaniecki 1976: 97-99). 
zwano by najpierw - najbliższych krewnych i dawnych sąsiadów". Jak piszą Znaniecki i Thomas ich funkcje musiały być, choćby częściowo, zastąpione „przez ludzi stosunkowo obcych, których w Polsce nigdy by nie poproszono o pomoc" (1976: 36). Z drugiej strony istniejąca w społeczeństwie amerykańskim tradycja zrzeszeń i zrzeszania się $^{24}$ sprzyjała powstawaniu opartych na nowych formach kontaktów ",towarzystw", w tym również tych o charakterze wzajemnej pomocy (Brożek (1988: 14-15).

Warto w tym miejscu zaznaczyć, iż samopomocowe stowarzyszenia kobiece, wpisywały się w amerykański system demokracji lokalnej (Nowaczewska 2010: 226). Działalność kobiet na szczeblu lokalnym była również łatwiejsza do zaaprobowania w świetle tradycyjnych wyobrażeń o roli kobiety w społeczeństwie. A dzięki „uzależnieniu" społeczeństwa amerykańskiego od stowarzyszeń, nieznające języka, nieposiadające żadnego zawodu, a często niepotrafiące czytać i pisać emigrantki z Polski "zaczęły coraz częściej odczuwać potrzebę łączności i koleżeństwa poza kręgiem rodzinnym" (Głos Polek 1936, nr 20: 2). Tworząc większe grupy, zwiększały szansę na przetrwanie w obcym, często nieprzyjaznym środowisku. Z kolei polskie emigrantki, które osiedliły się już wcześniej w Ameryce, chciały pomóc nowo przybyłym i chronić je przed wyzyskiem. W ten sposób tworzyła się swoistego rodzaju "sieć wsparcia". Z czasem chęć pomocy obecna w środowisku imigrantek zaczęła przyjmować coraz bardziej zinstytucjonalizowane formy. Okazywało się również, iż w bractwach i towarzystwach kościelnych "nie było miejsca dla kobiet szerszych poglądów, by mogły swoje zapatrywania uwypuklić" (Głos Polek 1936, nr 20: 2). Od lat 80. XIX wieku w Chicago pojawiały się pierwsze świeckie stowarzyszania kobiece, powstające bez inicjatywy Kościoła katolickiego. W 1884 roku w celu budowy domu dla dziewcząt oraz nauki robótek ręcznych powstało - działające zaledwie kilka miesięcy - Towarzystwo Grosz Polski (Karłowiczowa 1938: 25).

Wśród polskich emigrantek znalazły się jednak takie osoby, dla których oprócz zaspokojenia doraźnych potrzeb, coraz ważniejsza stawała się kwestia pozycji kobiet marginalizowanej w wielu dziedzinach. Działaczki te zaczęły domagać się równych praw dla obu płci. Jedną z najaktywniejszych, nazywaną liderką emancypacji kobiet polskich w Ameryce, była poetka Teofila Samolińska. Powstałe z jej inicjatywy w 1887 roku towarzystwa - Gwiazda Zwycięstwa, a zwłaszcza Towarzystwo Centralne Polek zwracały uwagę na bardzo istotną kwestię braku ubezpieczeń na życie dla kobiet. Żadne z istniejących w tamtym czasie stowarzyszeń i organizacji nie ubezpieczało bowiem kobiet, ze względu na wysokie ryzyko związane z tego typu świadczeniami. Wynikało ono między innymi z dużej śmiertelności kobiet przy porodach, ciężkich warunków pracy, następstwem których były częste wypadki oraz złych warunków higienicznych powodujących choroby (Karłowiczowa 1938: 25).

24 I Poprawka do Konstytucji USA zapewniająca wolność zgromadzeń i stowarzyszeń, uznaje „prawo obywateli amerykańskich do dobrowolnego stowarzyszania się w różnego rodzaju organizacje, związki zawodowe czy partie polityczne [...]" (Laidler 2007: 117). 
Należy podkreślić, że pozycja kobiet, zarówno pod względem społecznym, jak i prawnym, była pod koniec XIX wieku mocno ograniczona. Kobiety nie tylko nie posiadały prawa głosu, ale również nie miały prawa do wykształcenia na równi z mężczyznami, do zachowania własnego majątku, również po wyjściu za mąż, do podjęcia pracy zawodowej bez zgody męża, czy w końcu do równoprawnego z mężczyznami decydowania o sprawach rodzinnych (Ślęczka 1999: 59). W odpowiedzi na taką sytuację w krajach Europy Zachodniej powstał ruch sufrażystek. W USA świadomość wyborcza amerykańskich feministek dojrzewała zaś głównie w ruchach abolicjonistycznych. Jednak po emancypacji niewolników (1863-1865) oraz uznaniu ich za obywateli USA (1868-1870), działaczki ruchu kobiecego poczuły się oszukane przez swoich dotychczasowych sprzymierzeńców ze środowiska abolicjonistów, którzy nie wsparli dążeń kobiet. W swoich wspomnieniach Elizabeth Candy Stanton pisała:

Tak oto wyglądał światopogląd tego zbiorowiska filantropów ${ }^{25}$. Byliby wzburzeni myślą o przypalaniu gorącym żelazem ciał obecnych wśród nich szacownych niewiast, lecz ukrzyżowanie ich dumy i godności osobistej, upokorzenie ich ducha, wydawało im się zupełną drobnostką (cyt. za Graff 2004: 58).

W rezultacie amerykańskie sufrażystki z przełomu wieków domagały się praw wyborczych głównie dla białych amerykańskich kobiet, które uważały za "lepsze i jako takie przewyższające dawnych niewolników oraz imigrantów" (Graff 2004: 58-59). Polskie emigrantki doszły więc do wniosku, iż aby osiągnąć ważne dla nich cele muszą działać w ramach własnej grupy etnicznej. Początkowe próby zrzeszania się, łącznie z powstałym w 1885 roku Klubem Patriotycznych Polek, nie przyniosły jednak żadnych trwałych rezultatów ${ }^{26}$. Starania te, poza uzupełnieniem organizacyjnej luki, stopniowo uświadamiały jednak pochodzącym z różnych środowisk i regionów kobietom polskiego pochodzenia potrzebę zjednoczenia działań w ramach jednej centralnej organizacji.

„Idę stworzenia odrębnej organizacji dla kobiet, w której mogłyby służyć sprawom, o których wówczas wyłącznie mężczyźni dysponowani, podczas gdy kobiety nie miały do tych spraw dostępu choć by najpiękniejszą myśl podały. Ich zdania nie były wcale brane pod uwagę, były one upośledzone, uważane przeważnie za niedojrzałe, niewyrobione" - podjęła Stefania Chmielińska (Głos Polek 1936, nr 20: 1).

Z jej inicjatywy 22 maja 1898 roku w jej własnym mieszkaniu w Chicago zostało utworzone Towarzystwo Związku Polek w Ameryce. W październiku, nawołując do zjednoczenia polonijnych grup kobiecych, organizacja ta opublikowała „Odezwę do Polek w Ameryce”. Znalazło się w niej między innymi takie wezwanie: "Odzywamy się przeto niniejszym do Szanownych Polek i powołujemy takowe do łączności.

${ }^{25}$ Miano filantropów w dziewiętnastowiecznym społeczeństwie amerykańskim przysługiwało głównie mężczyznom, przede wszystkim ze względu na wiążący się z tą działalnością fakt dysponowania dużym majątkiem na ogólnokrajową skalę, co „miało przerastać umiejętności i możliwości kobiet" (Nowaczewska 2010: 227).

${ }^{26}$ Do początku XX wieku przetrwało jedynie, założone przez Teofilię Samolińską w południowo-wschodniej części Chicago, Towarzystwo Centralne Polek (Waldo 1980). 
Odzywamy się do wszystkich towarzystw żeńskich, jakie w osadach polskich znajdują się, by ręce podały nam do wspólnej pracy" (Odezwa do Polek w Ameryce 1898). Okazało się ono skuteczne i 12 listopada 1899 roku w sali Pułaskiego w Chicago doszło do pierwszego posiedzenia organizacyjnego Związku Polek w Ameryce (ZPwA), na którym wybrano tymczasowy zarząd organizacji ze Stefanią Chmielińską jako prezeską na czele. W skład ZPwA weszły: Towarzystwa Związku Polek w Ameryce, Towarzystwa św. Heleny oraz Towarzystwa Królewny Wandy (Głos Polek 1928, nr 20: 8). Po wielu próbach „[...] zupełnie świadome tego, że narażając się na uśmiech politowania, ironii i częste lekceważenie a ostatecznie pobłażanie, garstka kobiet polskich, nazywanych bojowniczkami za sprawą emancypacji, zebrała się razem i stworzyła Związek Polek w Ameryce" (Głos Polek 1923, nr 26: 1-2).

Na zwołanym w 1900 roku I Sejmie ${ }^{27}$ ZPwA przyjęto konstytucję, czyli ",kodeks, na którym opiera się działalność organizacji”, nazywanej też przez jej członkinie „drogowskazem” (Głos Polek 1936, nr 5: 1; Głos Polek 1936, nr 43: 12). Artykuł 2. określał trzy główne cele związku. Po pierwsze, było to zapewnienie wykluczonym dotąd kobietom rożnego rodzaju ubezpieczenia: „Celem Związku Polek jest wzajemna pomoc i ubezpieczenie płatne przez całe życie, 20-letnie, 7-letnie terminowe i 20-letnie wypłacalne za życia, oraz ubezpieczanie od urodzenia do 16 lat włącznie"28. „[...] ubezpieczenie to protekcja, to klucz do szczęścia, do spadku po tych, których nić życia się zerwała. Trzeba się na niepewną chwilę zabezpieczyć. Od kobiety to w największej mierze zależy, mąż jej nigdy prawie bronić nie będzie" - pisała redaktorka „Głosu Polek" Maria Kryszak (Głos Polek 1926, nr 35: 1).

Do momentu powstania Związku Polek żadna bowiem z ówczesnych organizacji polonijnych, zarówno Związek Narodowo Polski, jak i Zjednoczenie Polskie Rzymsko-Katolickie nie ubezpieczała samotnych kobiet - mógł to w ich imieniu zrobić jedynie ojciec lub mąż (Głos Polek 1949, nr 20: 1)29. W związku z czym w prasie polonijnej zaczęły pojawić się następujące wzmianki: „Po co ten nowy twór się ukazał? Przecież kobiety, choć nie mają prawa wstępować do naszych organizacyi same to z mężem mogą i z tem im dobrze. Tylko będą niepotrzebne swary i nieporozumienia" (Głos

27 I Sejmowi ZPwA przewodniczyła i wybrana prezeską została Genowefa Żółkowska. Z powodu choroby matki musiała jednak wyjechać i ostatecznie prezesostwo objęła Stefania Chmielińska (Głos Polek 1926, nr 7: 3). Na dyplomie honorowym, wręczonym Stefanii Chmielińskiej podczas obrad Sejmu ZPwA w 1936 roku, umieszczony został następujący wpis: „Pragnęłaś, aby ogół kobiet nie był ciemną masą, nie zdającą sobie sprawy z własnej wartości jako czynnika organizacyjno-twórczego" (Głos Polek 1936, nr 27: 1).

28 Pierwsza konstytucja Związku Polek w Ameryce zaginęła, dlatego posługuję się cytatami zaczerpniętymi od Jadwigi Karłowiczowej. Następne uchwalane konstytucje ZPwA ulegały licznym modyfikacjom (Karłowiczowa 1938: 187). Należy podkreślić, iż certyfikaty ubezpieczeniowe były wprowadzane kolejno w miarę upływu lat. I tak przykładowo certyfikat 7 letni uchwalony został na 17 Sejmie w 1935 roku (Głos Polek 1936, nr 5: 2).

29 „Prowadząc interes ubezpieczeniowy na wielką skalę, stoimy na trwałym gruncie zabezpieczenia naszych rodzin na wypadek śmierci, kiedy to pieniądz najbardziej jest potrzebny. Przez to podnosimy stan naszego posiadania i niesiemy ulgę ciężkim warunkom materialnym", pisała w pierwszym tomie historii Związku Polek w Ameryce Jadwiga Karłowiczowa (1938: 188). Por. Zielińska 1981: 19; Loryś 1980: 16. 


\section{SM̂PP}

Polek 1936, nr 17: 1,7). Wiele kobiet zamężnych korzystało z możliwości ubezpieczenia się przez swoich mężów. Postawa taka spotykała się z negatywnym odbiorem zarówno ze strony zarządu Związku Polek w Ameryce głoszącego hasło: „Kobieta do kobiecej organizacji", jak i samych członkiń. ${ }^{30}$

Drugim celem nowo powstałej organizacji było dbanie o zachowanie świadomości narodowej: „Celem Związku Polek w Ameryce jest utrwalenie ducha narodowego, utrzymanie ideałów polskich wśród młodszej generacji przez kształcenie jej w historii i literaturze polskiej, oraz wykazanie potrzeby stałego kontaktu z Polską, by tą drogą wyrobić w niej siły kulturalne, jakie posiada Naród Polski" (The Constitution... 1983: 5). Aktywność Związku Polek w tej dziedzinie przejawiała się między innymi w organizowaniu wycieczek do Polski, zakładaniu "Klubów Polskich Panien” - „pragnących mieć własne koło dla wymiany myśli oraz czytania polskiej literatury" (Głos Polek 1928, nr 7: 1-2, Głos Polek 1927, nr 30: 7), jak również poprzez propagowanie korzyści płynących z uprawiania sportu, co przejawiało się m.in. w organizowaniu przez Związek Polek "Skautingu, czyli harcerstwa dla dziewcząt" - uznawano bowiem, że "skauting uczy poważać swój własny honor, być lojalnym względem rodziny, kraju [...]" (Głos Polek 1929, nr 33: 1). Jak bowiem zauważył Marek Szczerbiński „[...] polonijne stowarzyszenia sportowe, poprzez łączenie sportu z działalnością kulturalno-oświatową [...], przyczyniły się do patriotycznego wychowania młodzieży i umacniania poczucia więzi z Macierzą" (1984: 118).

Kobiety z polonijnych społeczności wspierały również polskich kandydatów starających się o publiczne posady. Za przykład może posłużyć niniejszy fragment zamieszczony w "Głosie Polek" „[...] byłoby niekonsekwentnie i po tchórzowsku z naszej strony nie wspomnieć i nie poprosić o wgląd w tych wyborach przede wszystkim na dwóch rodaków - kandydatów na poważne stanowiska. Chciałybyśmy im do zwycięstwa szczerze dopomóc" (Głos Polek 1928, nr 44: 6) 31. Popierały również zaangażowanie się W działalność polityczną samych kobiet. "A że równouprawnienie nadaje zdolnym kobietom prawo do urzędu, o ile go potrafią zdobyć przeto niech lecą" (Głos Polek 1928, nr 46: 1).

Kwestia świadomości narodowej była szczególnie istotna, ponieważ większość imigrantów przybyłych do Ameryki w początkowym okresie tworzenia się polskiej zbiorowości etnicznej identyfikowało się głównie z "ojczyzną prywatną" (w rozumieniu Stanisława Osowskiego) oraz posiadali jedynie „cząstkowe” poczucie świadomości

30 Przykładem takiej reakcji był list jednej z nich ze stanu Massachusetts wysłany do redakcji „Głosu Polek": „[...] ubolewając wprost jak to szybko kobiety dają się zapisywać do męskich organizacji, bo wtedy mąż za nią zapłaci podatki, a ona nie potrzebuje troszczyć się zapłatą lub Konstytucją sobie głowę łamać (Głos Polek 1926, nr 39: 4).

${ }^{31}$ Amerykańscy badacze polskiego pochodzenia w zbiorze "Ethnic Politics in Urban America" (1978) podkreślają, iż aktywiści polonijni nie odegrali decydującej roli w polityce lokalnej do I wojny światowej. Joseph Wytrwal, analizując problemy II generacji, zwrócił z kolei uwagę na fakt, że działacze, którym Polonia zapewniła kariery polityczne, wycofywali się z aktywności w jej kręgach. Jako przykład Autor przytoczył postać K. Rozmarka (1977: 287). 
narodowej (posługując się określeniem Tadeusza Palecznego) (Paleczny 1989: 118). Doświadczenia Nowego Świata spowodowały, iż polscy emigranci uświadomili sobie przynależność do szerszej zbiorowości, jaką był naród polski. Ojczyzna w znaczeniu ideologicznym została więc wykształcona dopiero na ziemi amerykańskiej. Szczególnie istotną rolę $\mathrm{w}$ dokonywaniu się tego procesu należy przypisać organizacjom polonijnym ${ }^{32}$.

I wreszcie ZPwA miał również wspierać równouprawnienie i emancypację. Artykuł 2 konstytucji głosił, że organizacja ma "stać na straży honoru kobiety polskiej i bronić dobrej opinii w świetle faktów historycznych [...] zachęcać członkinie do życia samodzielnego i dopomagać do uzyskania wyższego wykształcenia" (Karłowiczowa 1938: 187). Wskazywano bowiem, że „[...] brak samodzielności czyni kobietę pieszczotliwą, którą można się bawić i rzucać z rąk do rąk, a ostatecznie w kąt rzucić" (Głos Polek 1926, nr 28: 1), a więc „aby dopiąć swego celu, aby spełnić obowiązki stanu swego, ciesząc się równouprawnieniem z mężczyzną, bardzo potrzebnym i użytecznym jest wykształcenie" (Głos Polek 1927, nr 2: 1).

Założycielki Związku Polek nie chciały zamykać się w wąskim kręgu zajętego własnymi sprawami towarzystwa. Nowo powstałą organizację identyfikowały bowiem jako powszechną, a więc docierającą ze swoją społeczno-oświatową działalnością do różnych kręgów polonijnych. Z jednej strony były to środowiska niewykształconych, często niepotrafiących czytać i pisać emigrantek z Polski. Dla tej grupy odbiorców wymowna stała się już sama symbolika sztandaru Związku Polek „,[...] z godłem miłości siostrzanej, który nas woła i zaprasza do siebie, a który tak dobitnie przedstawia nam lojalność, solidarność, życzliwość" (Głos Polek 1927, nr 38: 1). Możliwości kolejnej formy kontaktowania się z tą grupą odbiorców dawały posiedzenia grup i komisji, na których - jak pisała kronikarka Związku Polek w Ameryce Jadwiga Karłowiczowa: „ustnie możemy porozumiewać się [...]” (1938: 189). Taka możliwość wynikała z hierarchii organizacyjnej Związku Polek, w którym najmniejszą jednostką była grupa, skupiająca codzienne życie organizacyjne. „Organizatorka była jakby matką danej Grupy, do niej z uznaniem odnoszą się członkinie, winna ona baczyć, aby grupa przez nie założona nie upadła. Każda Grupa powinna liczyć 25 członkiń" (Głos Polek 1926, nr 9: 1; Głos Polek 1936, nr 7: 4). Powstanie grupy uprzedzało zakładanie towarzystwa, które starało się m.in. o fundusze dla niej. Z kolei nazwa patrona grupy określała charakter ideowy prowadzonej działalności33. Grupy oraz

32 Między innymi te przyczyny złożyły się na sformułowanie w latach poprzedzających I wojnę światową ideologii "czwartej dzielnicy Polski”, która identyfikowała Polaków „którzy w Ameryce, nie uciskani przez zaborców mogą i powinni przechowywać najwartościowsze cechy kultury polskiej, swoje działania podporządkować interesom kraju pochodzenia, z których najważniejsze było odzyskanie przez Polskę niepodległości" (Rokicki 1986: 40). Helena Znaniecka-Łopata uważała z kolei, że to współzawodnictwo o pozycję społeczną, a nie ideologia integrowała Polonię (1976).

33 Przykładowo Towarzystwo Seweryny Duchcińskiej, poetki, publicystki, tłumaczki, organizatorki pomocy dla rodzin powstańców styczniowych, zajmowało się głównie "wpajaniem patriotyzmu w członkinie" (Głos Polek 1936, nr 10: 1-2.). Z kolei Towarzystwo Świętej Anny za główny cel obrało sobie „opiekę nad chorymi, niesienie pomocy materialnej ubogim i sierotom" (Głos Polek, 1936, nr 21: 7). 
działające przy nich towarzystwa zrzeszały z kolei Komisje (Głos Polek 1926, nr 9: 1). Ich zadaniem poprzez odczyty, wykłady patriotyczne, obchody oraz „Konteksty Werbunkowe” była „propaganda i oświata” (Głos Polek, 1937, nr 8: 10). Najwyższą instytucją był zwoływany co cztery lata Sejm Walny, czyli "reprezentacyjna forma rządu Związku Polek w Ameryce”. "Sejm posiadał najwyższą władzę prawodawczą, wykonawczą i sądowniczą nad Zarządem Głównym, Grupami i każdą członkinią" (Głos Polek 1927, nr 30: 1). Na każdym poziomie organizacyjnym "wolno każdemu swe spostrzeżenia wyjawić" (Głos Polek 1926, nr 22: 4).

Wzajemnej komunikacji oraz koordynacji działań organizacji nie tylko na poziomie lokalnym, miało służyć wydawanie od 1902 r. własnego pisma pt. "Głos Polek”; początkowo w formie jednostronicowego comiesięcznego dodatku w "Dzienniku Narodowym", którego redakcją zajął się Franciszek Wołowski. Na 8 Sejmie w 1910 r. ustalono, iż "Głos Polek" będzie tygodnikiem, a jego redakcją zajmie się oficjalnie kobieta, którą została Stefania Laudyn-Chrzanowska34 (Głos Polek 1923, nr 26: 1-2). Adresowane do kobiet czytających zawierało podstawowe informacje, odezwy i spra-

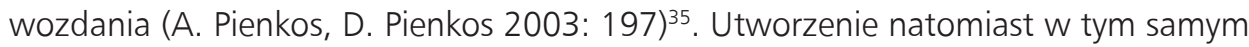
roku Wydziału Oświaty, pozwoliło ZPwA na współpracę z wybitnymi kobietami z Polski, jak Maria Konopnicka czy Eliza Orzeszkowa, oraz udzielanie pożyczek bez oprocentowania dla „zdolnych uczennic na wyższe nauki”36 (Głos Polek 1929, nr 33: 1).

Związek Polek w Ameryce oferował także od 1912 r. program dla młodych dziewcząt. Pierwotnym pomysłem Zarządu Związku Polek w Ameryce było utworzenie z dziewcząt w wieku od 12 do 16 lat, niemogących się jeszcze ubezpieczać, towarzystwa pod nazwą "Wianki Związku Polek” (Głos Polek 1912, nr 43: 1). Jednym z celów pracy wśród dziewcząt zgrupowanych w „Wiankach”, było zachowanie kultury i języka polskiego; jak pisała Jadwiga Karłowiczowa program miał: „[...] zaznajamiać [je] z wartościami kultury narodowej, inaczej bowiem, będzie ona zawsze odnosiła się do polskości z pewnego rodzaju niedowierzaniem". Z kolei dzięki prowadzonym w "Wiankach" kursom przygotowawczym zapewniano ciągłość działalności

34 Stefania Laudyn-Chrzanowska, podczas wystąpienia na Konwencji Towarzystwa Dziennikarzy i Literatów w dniach 2 i 3 października 1911 roku, w wygłoszonej mowie wyraźnie opowiedziała się za powstawaniem związków zawodowych i równymi prawami dla kobiet. Zajęła tym samym bardzo ważny głos w kwestii kobiecej, zauważając: „Z pośród mnóstwa przeobrażeń, spraw i prądów nowych, obejmujących życie obecne społeczeństw i narodów - na powierzchnię i na czoło zadań przyszłościowych bieżącej chwili wysuwa się - sprawa kobiety" (Sprawa polska w Ameryce Północnej na pierwszym Zjeździe Towarzystwa Literatów i Dziennikarzy Polskich w Syracuse, N.Y. w dniach 2 i 3 października 1911 1912: 151).

35 O roli jaką pełnił „Głos Polek” pisała do jego redakcji członkini grupy 177 Wacława Kaczyńska: „[...] mieszkam z dala od osad polskich. Interesuje mnie wszystko, co się tyczy naszej organizacji, a nasz organ „Głos Polek" dostarcza mi właśnie te wszystkie wiadomości, których pragnę” (Głos Polek 1926, nr 39: 1).

${ }^{36} \mathrm{Na}$ rozczarowanie Polonii amerykańskiej w stosunku do osób, które dzięki polonijnej pomocy stypendialnej zdobyły wykształcenie, a potem wycofały się z życia polonijnego zwrócił uwagę wspominany już Joseph Wytrwal (1977: 265-287). Podobne spostrzeżenia można przeczytać w "Głosie Polek": „W środowisku polskim niejedna osoba kosztem takiej zapomogi wybiła się, otrzymała potem intratne posady, lecz o pożyczce zapomniała" (Głos Polek 1926, nr 39: 1). 
organizacyjnej „poprzez napływ [...] szereg[u] młodych dziewcząt i kobiet, które z poświęceniem oddadzą się pracy wśród naszego zespołu" (Karłowiczowa 1938: 192-193). W 1917 roku organizacja otrzymała zezwolenia na ubezpieczenie nieletnich członków pod nazwą „Wianki” (A. Pienkos, D. Pienkos 2003: 203).

Skutkiem powstania Związku Polek w Ameryce jako organizacji o charakterze samopomocowym (bratniackim) było przede wszystkim zabezpieczenie ekonomiczne kobiet polskiego pochodzenia, jak również poczucie „bycia u siebie” oraz forma społecznego awansu i stworzenie wokół organizacji opiniotwórczej elity kobiet. Dzięki Związkowi Polek inne organizacje wzajemnej pomocy nadały kobietom równouprawnienie (Dmuchała 2008: 54-55).

\section{Podsumowanie}

Okoliczności, w jakich krystalizowała się idea powstania Związku Polek w Ameryce, są doskonałą ilustracją ewolucji działalności pomocowej Polek w Stanach Zjednoczonych. Przebiegała ona zgodnie ze wzorem wskazywanym w pionierskim opracowaniu W. Thomasa i F. Znanieckiego „Chłop Polski w Europie i Ameryce”: od organizacji nieformalnych opartych na więzi osobistej, w których „wzajemna pomoc udzielana jest sporadycznie, od przypadku do przypadku, za pomocą zbiórek dokonywanych na rzecz jednostki czy rodziny, którą dotknęło nieszczęście”, poprzez "regularny system wzajemnego ubezpieczenia od śmierci i choroby” (1976: 36) i powstanie „towarzystwa”, aż po „[...] scaleni[e] oddzielnych grup lokalnych w jeden system ubezpieczenia" z obowiązkowym systemem składek, który „[...] zapobiega w pewnych granicach temu, żeby osobiste nieporozumienia nie stały się przyczyną rozwiązania stowarzyszenia" (1976: 37). Sposób funkcjonowania kobiet w polonijnej społeczności doskonale pokazuje również zmianę ich postawy życiowej w momencie zetknięcia z nową amerykańską rzeczywistością. „Jako kobiety - obywatelki tego kraju, gdzie Amerykanki bardzo wiele dla dobra drugich czynią - bądźmy ich naśladowczyniami" (Głos Polek 1936, nr 50: 1, 12). Stąd m.in. pomysł stworzenia Fundacji ZPwA, udzielanie różnego rodzaju stypendiów czy budowa domu dla samotnych kobiet.

Zaangażowanie polskich emigrantek w działalność na rzecz własnej etnicznej społeczności pokazuje z jednej strony ich aktywną obecność w sferze publicznej, uwidaczniającą się w podejmowaniu nowych, nieznanych dotąd ról, ale i wywieraniu pewnych nacisków politycznych zanim uzyskały prawo głosu, będących konsekwencją amerykańskiego, zurbanizowanego stylu życia i demokratycznych idei. Z drugiej zaś strony przywiązanie do polskich tradycji i katolickich wartości przejawiało się w procesie tworzenia różnego rodzaju substytutów dla pozostawionych w kraju pochodzenia przyzwyczajeń. A zachowanie tożsamości narodowej zarówno pod obcym panowaniem, jak i na emigracji „stanowiło «pewnego rodzaju» wspólny mianownik, który odniósł się zarówno do obszarów pozostających pod zaborami, jak i państw 
imigracyjnych" (Brożek 1988: 29). Niewątpliwie kobiety polskiego pochodzenia umiejętnie korzystały z doświadczeń wyniesionych z kraju pozbawionego własnej państwowości, aktywnie wcielając je w swoją działalność w Nowym Świecie.

\section{Bibliografia}

\section{Dokumenty}

Odezwa do Polek w Ameryce. „Kurier Polski”, Milwaukee, 25 X 1898.

The Constitution and By-laws of the Polish Women's Alliance of America, Illinois 1983.

\section{Gazety}

"Głos Polek", nr 43, 24 XI 1912.

"Głos Polek", nr 26, 27 VI 1923.

"Głos Polek", nr 7, 18 ॥ 1926.

"Głos Polek", nr 9, 4 III 1926.

„Głos Polek”, nr 22, 3 VI 1926.

"Głos Polek", nr 28, 15 VII 1926.

„Głos Polek", nr 35, 2 IX 1926.

"Głos Polek", nr 39, 30 IX 1926.

„Głos Polek", nr 2,13। 1927.

"Głos Polek", nr 19, 12 VI 1927.

"Głos Polek", nr 30, 28 VII 1927.

"Głos Polek", nr 38, 22 IX 1927.

"Głos Polek", nr 7,16 II 1928.

"Głos Polek", nr 20, 17 V 1928.

"Głos Polek", nr 35, 30 VIII 1928.

"Głos Polek", nr 44, 1 XI 1928.

"Głos Polek", nr 46, 15 XI 1928.

"Głos Polek", nr 33, 15 VIII 1929.

"Głos Polek", nr 5, 30 I 1936.

"Głos Polek", nr 7, 13 ॥ 1936.

"Głos Polek", nr 20,14 V 1936.

„Głos Polek", nr 27, 2 VII 1936.

"Głos Polek", nr 2, 14 । 1937.

„Głos Polek", nr 8, 25 III 1937.

\section{Książki, rozdziały w książkach oraz artykuły naukowe}

Andrzejewski A., Dziembowska J. (1977), Pamiętniki emigrantów: Stany Zjednoczone, t. 2, Warszawa: Wydawnictwo Książka i Wiedza.

Anker L. (1988), Women, Work and Family: Polish, Italian and East European Immigrants in Industrial Connecticut, 1890-1940, "Polish American Studies”, nr 2, s. 30-31.

Babiński G. (2009), Polonia w USA: na tle przemian amerykańskiej etniczności, Kraków: Krakowskie Towarzystwo Edukacyjne - Oficyna Wydawnicza AFM. 
Barett J.R. (1987), Work and Community in the Jungle: Chicago's Packinghouse Workers, 18941922, Urbana-Chicago: University of Illinois Press.

Bodnar J. (1987), The Transplanted: a History of Immigrants in Urban America, Bloomington; Indianapolis: Indiana University Press.

Bodnar J., Simon R., Weber M.P. (1983), Lives of Their Own: Blacks, Italians, and Poles in Pittsburgh, 1900-1960, Urbana-Chicago-London: University of Illinois Press Paperback.

Bokszańska G. (2004) Ubiór w teatrze życia społecznego, Łódź: Wydawnictwo Politechnika Łódzka. Brożek A. (1988), Geneza i przemiany organizacji polonijnych w Europie i Ameryce, w: Babiński, G. (red.) Studia nad organizacjami polonijnymi w Ameryce Północnej, Wrocław; Warszawa: Zakład Narodowy im. Ossolińskich; Wydawnictwo Polskiej Akademii Nauk.

Chałasiński J. (1935) Parafia i szkoła parafialna wśród emigracji polskiej w Ameryce. Studium dzielnicy polskiej w Południowym Chicago, "Przegląd Socjologiczny” t. 3.

Chrobot L.F. (1982), The Pilgrimage from Gemeinschaft to Gesselschaf: Socjological Functions of Religion in the Polish American Community, w: Renkiewicz F. (red.) The Polish Presence in Canada and America, Toronto: Multicultural History Society of Ontario.

Dmuchała J. (2008), Związek Polek w Ameryce jako ruch kobiecy, „Przegląd Polonijny”, z. 1-2. Encyklopedia katolicka, Lublin: Wydawnictwo Katolickiego Uniwersytetu Lubelskiego 1989.

Ethnic politics in urban America: the Polish experience in four cities (1978), / ed. by Angela T. Pienkos (red.), Chicago: Polish American Historical Association.

Galush W.J. (1990), Purity and Power: Chicago Polonian Feminist, 1880-1914 „Polish American Studies", nr 1, s. 11.

Galush W.J. (1996), Polish Americans and Religion, w: J.J. Bukowczyk (red.), Polish Americans and Their History: Community, Culture, and Politics, Pittsburgh: University of Pittsburgh Press.

Graff A. (2004), Więcej niż kontekst - kwestia rasowa a feminizm w Stanach Zjednoczonych, w: Radkiewicz M. (red.), Gender-konteksty, Kraków: Wydawnictwo Rabid.

Karłowiczowa J. (1938), Historia Związku Polek w Ameryce: przyczynki do poznania duszy wychodztwa polskiego Ameryki Północne, Chicago: Polish Women's Alliance of America.

Knothe M.A. (2005), Za chlebem, po męża czy dla siebie? Strategie życiowe polskich migrantek, w: Zamojski J. (red.) Kobiety i młodzież w migracjach. Migracje i społeczeństwo, t. 10, Warszawa: Wydawnictwo Neriton.

Kraft C. (2005) Państwo wobec rodziny - polityka państw europejskich w XIX i XX wieku - Polska na tle europejskim, w: Kałwa D., Walaszek A., Żarnowska A. (red.), Rodzina - prywatność intymność: dzieje rodziny polskiej w kontekście europejskim: zbiór studiów, Warszawa: Wydawnictwo DiG.

Kruszka W. (1937), Historja Polska w Ameryce: od czasów najdawniejszych aż do najnowszych, t. 1, Milwaukee: Kuryer Publishing Co.

Kujawa S. R.M. (1979), Madonna College. It's History of a Higher Education 1937-1977, PhD Thesis, Detroit: Wayne State University.

Kumor B. (1995), Historia Kościoła, Lublin: Wydawnictwo Katolickiego Uniwersytetu Lubelskiego. Laidler P. (2007), Konstytucja Stanów Zjednoczonych Ameryki: przewodnik, Kraków: Wydawnictwo Uniwersytetu Jagiellońskiego.

Leś B. (1981), Kościót w procesie asymilacji Polonii amerykańskiej: przemiany funkcji polonijnych instytucji i organizacji religijnych w środowisku Polonii chicagowskiej, Wrocław; Warszawa: Zakład Narodowy im. Ossolińskich. Wydawnictwo Polskiej Akademii Nauk.

Liguori [Pakowska] S. M., HFN (1946), Mother Mary Siedlecka in America, „Polish American Studies", nr 1-2, s. 30-35. 


\section{SM̂PP}

Loryś M. (1980), Historia Związku Polek w Ameryce, t. 2, Chicago: Wydawnictwo Związku Polek w Ameryce.

Misner B. (1988), Highly Respectable and Accomplished Ladies: Catholic Women Religious in America, 1790-1850, New York: Garland.

Nowaczewska R. (2010), Migracje kobiet: Od „Lady Bountiful” do kobiecej filantropii - awans zawodowy i/czy społeczny? Rola kobiet w rozwoju dobroczynności w Stanach Zjednoczonych, w: Chlebowska A., Sierakowska K. (red.) Kobiety i procesy migracyjne, Warszawa: Wydawnictwo Neriton.

Paleczny T., (1989), Ewolucja ideologii i przemiany tożsamości narodowej Polonii w Stanach Zjednoczonych w latach 1870-1970, Warszawa: Państwowe Wydaw. Naukowe; Kraków: nakł. UJ.

Parot J.J. (1982), The ", Serdeczna Matko" of the Sweatshops: Maritel and Family Crises of Immigrant Working-Class Women in Late Nineteenth Century Chicago, win: Renkiewicz F. (red.), The Polish Presence in Canada and America in Canada and America, Toronto: Multicultural History Society of Ontario.

Pastusiak L. (1978), Polacy w Chicago przed I/ wojną światową, cz. II "Przegląd Polonijny”, z. 4, s. 9. Pienkos A., Pienkos D. (2003), "In the Ideals of Women is the Strength of a Nation": A History of the Polish Women's Alliance of America, New York: Columbia University Press.

Plucińska M. (1993), Związek Polek w Ameryce, „Almanach Polonii”, s. 139.

Praszałowicz D. (1986), Amerykańska etniczna szkoła parafialna: studium porównawcze trzech wybranych odmian instytucji, Wrocław; Warszawa: Zakład Narodowy im. Ossolińskich; Wydawnictwo Polskie Akademii Nauk.

Praszałowicz D. (1988), Przemiany oświaty polonijnej w USA, w: Kubiak. H., Kusielewicz E., Gromada T. (red.), Polonia amerykańska przeszłość i współczesność, Wrocław; Warszawa: Zakład Narodowy im. Ossolińskich; Wydawnictwo Polskiej Akademii Nauk.

Radziallowski T.C. (1996), Family, Women and Gender. The Polish Experience, w: J.J. Bukowczyk (red.), Polish Americans and Their History: Community, Culture, and Politics, Pittsburgh: University of Pittsburgh Press.

Rokicki J. (1986), Obrzęd religijny jako symbol grupy etnicznej. Konflikt o pasterkę $w$ diecezji Scranton, Pa, w latach 1935-1936, "Przegląd Polonijny”, z. 4.

Rokicki J. (1992), Język polski jako wartość społeczne a proces asymilacji Polonii amerykańskiej, "Przegląd Polonijny”, z. 2.

Sprawa polska w Ameryce Pótnocnej na pierwszym Zjeździe Towarzystwa Literatów i Dziennikarzy Polskich w Syracuse, N.Y. w dniach 2 i 3 października 1911, Wydawnictwo W. Dyniewicz, Chicago 1912.

Szczerbiński M. (1984), Rola sportu w utrzymaniu więzi między zbiorowościami polonijnymi a Macierzą w latach 1918-1939, Katowice: Akademia Wychowania Fizycznego w Katowicach.

Ślęczka K. (1999), Feminizm, Katowice: Wydawnictwo Książnica.

Taras P. (1989), Polonia w Detroit: problem kulturowej tożsamości i społecznego awansu. Socjologiczne studium spoteczności etnicznej w USA, Warszawa: Wydawnictwo Pallottinum.

Taraasa P. (1989), Polonia w Detroit: problem kulturowej tożsamości i społecznego awansu: socjologiczne studium społeczności etnicznej w USA, Warszawa : Pallottinum.

Thomas W., Znaniecki F. (1976), Chłop polski w Europie i Ameryce, t. 1-5, Warszawa: Ludowa Spółdzielnia Wydawnicza.

Tulia Doman S. M., CSSF (1953), Mother Angela Truszkowa, Foundress of Felicjan Sister, „Polish American Studies", nr 3-4, s. 65-94.

Wachtl K. (1944), Polonia w Ameryce: dzieje i dorobek, Filadelfja: nakł. autora. 
Walaszek A. (1988), Polscy robotnicy, praca i związki zawodowe w Stanach Zjednoczonych Ameryki 1880-1922, Wrocław; Warszawa: Zakład Narodowy im. Ossolińskich. Wydawnictwo Polskie Akademii Nauk.

Walaszek A. (1993), Dzieci, dzieciństwo i etniczność w Stanach Zjednoczonych do lat trzydziestych XX wieku, "Przegląd Polonijny", z. 2, s. 48.

Walaszek A. (1994) Światy imigrantów: tworzenie polonijnego Cleveland 1880-1930, Kraków: Wydawnictwo Nomos.

Walaszek A. (1997), Masowa konsumpcja i wielki kryzys ekonomiczny, w: Żarnowska A, Szwarc A. (red.), Kobiety i kultura życia codziennego wiek XIX i XX, Warszawa: Wydawnictwo DiG.

Walaszek A. (2007), Migracje Europejczyków 1650-1914, Kraków: Wydawnictwo Uniwersytetu Jagiellońskiego.

Waldo A.L. (1980), Teofila Samolińska. Matka Związku Narodowego Polskiego w Ameryce, Chicago: nakł. prywatny.

Warat M. (2008), Etniczność i gender - między teorią a praktyką, w: Slany, K. (red.), Migracje kobiet. Perspektywa wielowymiarowa, Kraków: Wydawnictwo Uniwersytetu Jagiellońskiego, 2008.

Wawrykiewicz M. (1985), Etniczne organizacje ubezpieczeniowe W USA, "Przegląd Polonijny", z. 4 , s. 48.

Weinberg S.S. (1989), The World of Our Mothers: The Lives of Jewish Immigrant Women, New York: Schocken Books Inc.

Wytrwal J.A. (1977), Behold! the Polish-Americans, Detroit: Endurance Press.

Zielińska H. (1981), Historia Związku Polek w Ameryce 1898-1979. Sprawy organizacyjne, t. 3, Chicago: Wydawnictwo Związku Polek w Ameryce.

Znaniecka - Łopata H. (1977), Funkcje stowarzyszeń dobrowolnych w polonijnej wspólnocie etnicznej, „Studia Polonijne”, t. 3, s. 92.

Znaniecka-Łopata H. (1997), Przenikanie się publicznej i prywatnej sfery życia: wyzwanie rzucone przez kobiety społeczeństwu amerykańskiemu, w: Kozyra-Kowalski S., Przestalski A., Włodarek J. (red.), Krytyka rozumu socjologicznego: praca zbiorowa wydana z okazji 100-lecia urodzin Tadeusza Szczurkiewicza, Poznań: Wydawnictwo Zysk i Spółka.

Znaniecki- LLopata. H. (1976), Polish Americans: status competition in an ethnic community, Englewood Cliffs: Prentice-Hall.

Żarnowska A. (2013) Kultura czasu wolnego w przestrzeni wielkomiejskiej - kobiety w środowisku robotniczym-XIX-XX, w: Janiak-Jasińska A., Sierakowska K., Szwarc A. (red.), Kobieta i rodzina w przestrzeni wielkomiejskiej na ziemiach polskich w XIX i XX wieku / Anna Żarnowska, Instytut Historyczny Uniwersytetu Warszawskiego; Towarzystwo Miłośników Historii, Warszawa: Wydawnictwo DIG.

Żarnowska A. (2013), Prywatna sfera życia rodzinnego i zewnętrzny świat życia publicznego - bariery i przenikanie (przełom XIX i XX wieku), w: Janiak-Jasińska A., Sierakowska K., Szwarc A. (red.), Kobieta i rodzina w przestrzeni wielkomiejskiej na ziemiach polskich w XIX i XX wieku I Anna Żarnowska, Instytut Historyczny Uniwersytetu Warszawskiego; Towarzystwo Miłośników Historii, Warszawa: Wydawnictwo DIG.

Żarnowska A., Szwarc A. (2013), Ruch emancypacyjny i stowarzyszenia kobiece na ziemiach polskich przed odzyskaniem niepodległości - dylematy i ograniczenia. Wprowadzenie, w: Janiak-Jasińska A., Sierakowska K., Szwarc A. (red.), Kobieta i rodzina w przestrzeni wielkomiejskiej na ziemiach polskich w XIX i XX wieku / Anna Żarnowska, Instytut Historyczny Uniwersytetu Warszawskiego; Towarzystwo Miłośników Historii, Warszawa: Wydawnictwo DIG. 